\title{
MODEL PENATAAN KAWASAN SITU UNTUK REDUKSI RISIKO BENCANA BANJIR DI JAKARTA
}

\section{LAKE REGULATIONS AREA MODEL FOR RISK REDUCTION FLOOD DISASTER IN JAKARTA}

\author{
Lian Yuanita Andikasari dan Deliyanti Ganesha \\ Pusat Teknologi Reduksi Risiko Bencana, BPPT, \\ JI. M. H. Thamrin No. 8, Jakarta \\ 10340 \\ e-mail: lian.yuanita@bppt.go.id; deliyanti.ganesha@bppt.go.id
}

\begin{abstract}
Flood is ecologically a physical event that occurs in the human environment. Limited land that can not accommodate development in the Jakarta area, triggering development in the area around the river. Development in the area around the river basin has changed the land use pattern. The area around the river is a flood plain so if the area is built into residence or settlement then the settlement will be affected if the river water overflows and causes flooding. The area of Jakarta is passed by 13 rivers that often overflow in the rainy season including Angke and Pesanggrahan Lake. Land use in the Angke-Pesanggrahan Watershed greatly affects the occurrence of floods in the Angke Pesanggrahan Watershed. The more areas are built on the watershed, the water absorption area is also less so that water in Kali Angke and Pesanggrahan overflows and causes flooding. Therefore, it is necessary to classify the type of settlement zone and also some methods of water absorption such as biopori and absorption well as one of the ways to reduce flood risk.
\end{abstract}

Keywords: Flood, Watershed, Angke-Pesanggrahan, Biopori, Absorption Well

\begin{abstract}
ABSTRAK
Banjir secara ekologis merupakan peristiwa fisik yang terjadi di dalam lingkungan hidup manusia. Keterbatasan lahan yang tidak dapat menampung pembangunan di wilayah Jakarta, memicu pembangunan di daerah sekitar aliran sungai. Pembangunan di daerah sekitar aliran sungai telah mengubah pola penggunaan lahan. Daerah sekitar sungai merupakan dataran banjir sehingga jika daerah tersebut dibangun menjadi tempat tinggal ataupun permukiman maka permukiman tersebut akan terkena dampak jika air sungai meluap dan menyebabkan banjir. Wilayah Jakarta dilewati oleh 13 sungai yang sering meluap pada musim hujan termasuk Kali Angke dan Pesanggrahan. Penggunaan lahan pada DAS Angke-Pesanggrahan sangat mempengaruhi terjadinya banjir di DAS Angke - Pesanggrahan. Semakin banyak area terbangun pada DAS tersebut maka area penyerapan air juga semakin sedikit sehingga membuat air di Kali Angke dan Pesanggrahan meluap dan menyebabkan banjir. Sehingga perlu adanya klasifikasi tipe zona pemukiman dan juga beberapa metode penyerapan air seperti biopori dan sumur resapan sebagai salah satu cara untuk reduksi risiko banjir.
\end{abstract}


Katakunci: Banjir, Daerah Aliran Sungai (DAS), Angke-Pesanggrahan Biopori, Sumur Resapan

\section{PENDAHULUAN}

\subsection{Latar Belakang}

Banjir merupakan masalah yang sering terjadi di Jakarta. Segala upaya dari program jangka pendek dan program jangka panjang telah dilakukan tetapi hasilnya tidak memuaskan sehingga masalah banjir tetap terjadi setiap tahun. Banjir dapat berupa genangan pada lahan yang biasanya kering seperti pada lahan pertanian, permukiman, pusat kota. Banjir dapat juga terjadi karena debit atau volume air yang mengalir pada suatu sungai atau saluran drainase melebihi atau diatas kapasitas pengalirannya.

Pembangunan lahan di wilayah Jakarta sangat pesat sehingga dengan keterbatasan lahannya memicu pembangunan di daerah sekitar aliran sungai. Hal tersebut, merubah pola penggunaan lahan (Rosyidie, 2013).
Daerah sekitar sungai merupakan dataran banjir sehingga jika daerah tersebut dibangun menjadi tempat tinggal ataupun permukiman maka permukiman tersebut akan terkena dampak jika air sungai meluap dan menyebabkan banjir. Wilayah Jakarta dilewati oleh 13 sungai yang sering meluap pada musim hujan salat satunya adalah Kali Angke dan Pesanggrahan (Syarif, 2008). Semakin banyak area terbangun pada DAS tersebut maka area penyerapan air juga semakin sedikit sehingga membuat air di Kali Angke dan Pesanggrahan meluap dan menyebabkan banjir.

\section{Berdasarkan BPBD Jakarta tahun}

2012 Genangan banjir di Jakarta dominan berada di bagian utara yaitu Jakarta Utara semakin ke selatan genangan banjir semakin berkurang. Lokasi genangan banjir di DAS Angke Pesanggrahan dapat dilihat pada Gambar 1.

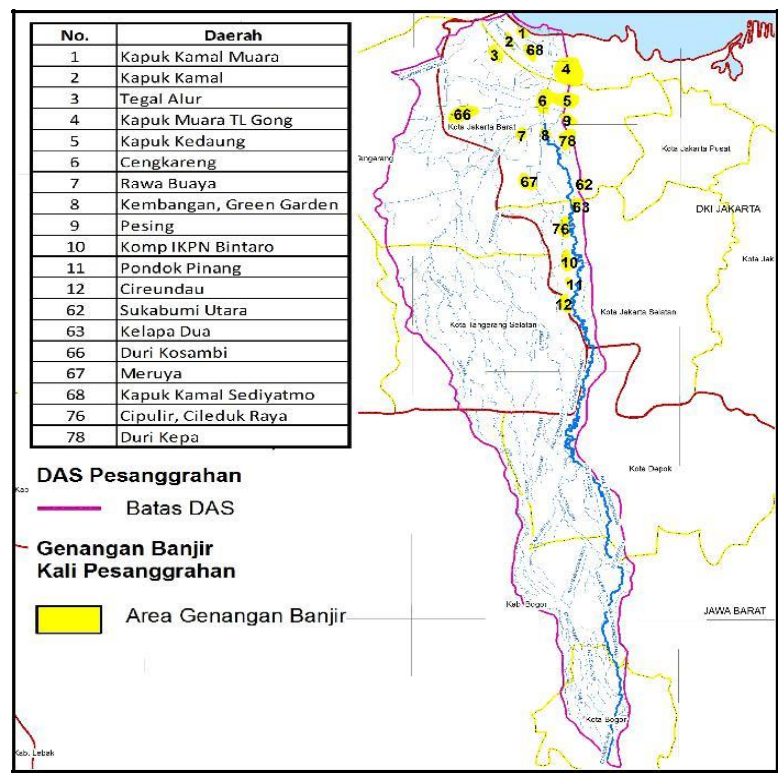

Gambar 1. Peta Genangan Banjir pada DAS Angke - Pesanggrahan.

Ada beberapalokasi tergenang banjir, yaitu: Kapuk Kamal Muara, Kapuk Kamal, Tegal Alur, Kapuk yang Muara TL Gong, Kapuk Kedaung, Cengkareng, Rawa Buaya, KembanganGreen Garden, Pesing, Komp IKPN 
Bintaro, Pondok Pinang, Cireundau, Sukabumi Utara, Kelapa Dua, Duri Kosambi, Meruya, Kapuk Kamal Sediyatmo, Cipulir-Cileduk Raya, dan Duri Kepa.

\subsection{Tujuan}

Penelitian ini dimaksudkan untuk membuat rekomendasi metode penyerapan air pada yang tepat untuk DAS Angke-Pesanggrahan sebagai model penataan kawasan situ untuk reduksi risiko bencana banjir di Jakarta.

\section{METODA PENELITIAN}

Penelitian ini dilakukan dengan beberapa langkah dan metode sebagai berikut:

a. Melakukan studi pustaka dan literatur baik data, informasi, maupun

penelitian sebelumnya melalui penelusuran literatur berupa jurnal, buku atau website.

b. Melakukan survei lapangan.

Tabel

c. Mengumpulan data DEM SRTM dari BPDAS Ciliwung Citarum, BIG, dan BPBD Jakarta.

d. Mengolah dan analisi data yang diperoleh dari referensi serta data dari hasil survei lapangan.

\section{HASIL DAN PEMBAHASAN}

\subsection{Kondisi Topografi Penggunaan Lahan di DAS Angke-Pesanggrahan}

Berdasarkan informasi genangan banjir di DAS Angke-Pesanggrahan, genangan banjir dominan berada di bagian utara Jakarta. Hal tersebut sangat didukung dengan kondisi topografi Jakarta yang semakin ke utara ketinggiannya semakin rendah. Ketinggian DAS Angke Pesanggrahan berdasarkan data DEM SRTM ada 10 klasifikasi dan interval 30 mdpl. Kelas ketinggian tertinggi yaitu kelas ketinggian 270-300 mdpl yaitu berada di Kabupaten Bogor, Jawa Barat. Kelas ketinggian dengan luas terbesar pada DAS Angke Pesanggrahan adalah kelas ketinggian 0 - $30 \mathrm{~m}$ dpl dan berada di Jakarta dan Kabupaten Tangerang. Genangan banjir dominan terdapat pada kelas ketinggian 0 - 30 mdpl yaitu bagian utara DAS. Genangan banjir yang terjadi pada daerah tersebut secara langsung dipengaruhi oleh penggunaan lahan pada daerah tersebut. Peta Penggunaan Lahan di DAS Angke Pesanggrahan dapat dilihat pada Gambar 2.

Dari peta penggunaan lahan dapat diidentifikasijenislandusedan

luasannya pada DAS AngkePesanggarahan. Landuse dengan luas terbesar adalah permukiman yaitu sebesar $32.528 \mathrm{Ha}$ atau $66,75 \%$ dari luas keseluruhan dan tersebar merata pada DAS.

\section{Landuse DAS Angke - Pesanggrahan 2012}

\begin{tabular}{|l|r|r|}
\hline $\begin{array}{c}\text { Landuse DAS } \\
\text { Angke- } \\
\text { Pesanggrahan }\end{array}$ & Hektar & \multicolumn{1}{c|}{$\%$} \\
\hline $\begin{array}{l}\text { Hutan mangrove } \\
\text { sekunder }\end{array}$ & 39,19 & 0,08 \\
\hline Hutan tanaman & 1,31 & 0,00 \\
\hline Lapangan udara & 430,93 & 0,88 \\
\hline Pemukiman & 32528.08 & 66,75 \\
\hline Perkebunan & 97,43 & 0,20 \\
\hline $\begin{array}{l}\text { Pertanian lahan } \\
\text { kering }\end{array}$ & 7044,31 & 14,46 \\
\hline $\begin{array}{l}\text { Pertanian lahan } \\
\text { kering campur }\end{array}$ & 2951,46 & 6,06 \\
\hline Sawah & 4960,64 & 10,18 \\
\hline Semak/belukar & 55,28 & 0,11 \\
\hline Tambak & 380,90 & 0,78 \\
\hline Tubuh air & 242,84 & 0,50 \\
\hline Total & 48732,37 & 100,00 \\
\hline
\end{tabular}




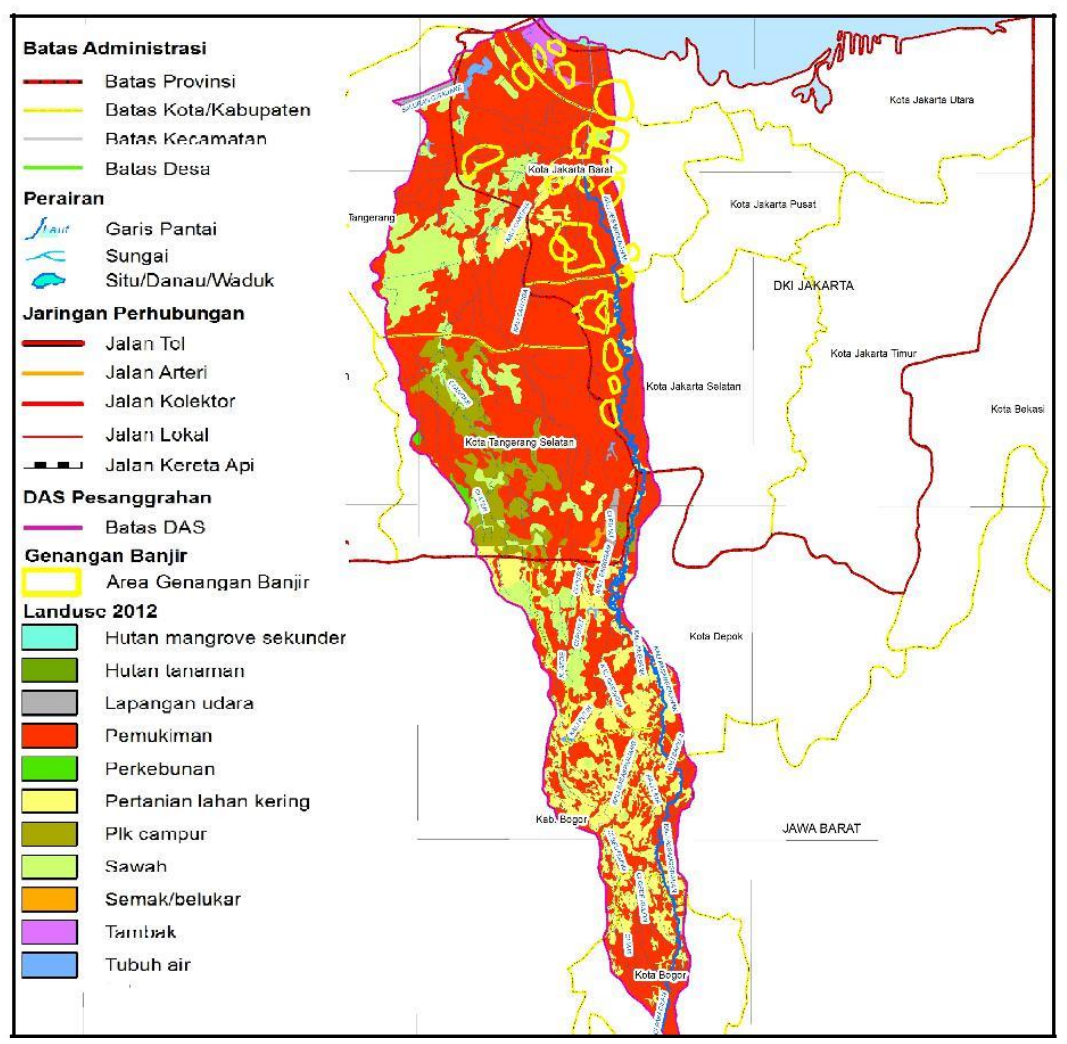

Gambar 2. Penggunaan Lahan DAS Angke - Pesanggrahan 2012

Tabel 2. Landuse pada Genangan

Banjir di DAS Angke-

Pesanggrahan 2012

\begin{tabular}{|l|r|r|}
\hline $\begin{array}{l}\text { Landuse pada } \\
\text { Genangan }\end{array}$ & Hektar & $\%$ \\
\hline Pemukiman & 2083,36 & 89,76 \\
\hline $\begin{array}{l}\text { Pertanian lahan } \\
\text { kering }\end{array}$ & 43,39 & 1,87 \\
\hline Sawah & 96,18 & 4,14 \\
\hline Tambak & 88,99 & 3,83 \\
\hline Tubuh air & 9,06 & 0,39 \\
\hline Total & 2320,97 & 100,00 \\
\hline
\end{tabular}

Berdasarkan tabel di atas maka dapat diketahui landuse pada genangan banjir didominasi oleh permukiman. Permukiman merupakan area terbangun yang dapat menghambat penyerapan air sehingga air yang hujan tidak dapat

masuk ke dalam tanah dan menyebabkan meluapnya air sungai dan menimbulkan genangan.

\subsection{DAS dan SubDAS Pesanggrahan}

Setelah mengetahui kondisi genangan banjir, penggunaan lahan, dan topografi pada DAS AngkePesanggrahan maka dapat disimpulkan bahwa genangan banjir terjadi pada daerah yang rendah yaitu bagian hilir dengan dominasi penggunaan lahan permukiman. Berdasarkan UndangUndang Nomor 7, Tahun 2004 Tentang Sumber Daya Air, serta program otonomi daerah maka konsep pengelolaan sungai harus secara terpadu (one river-one plan-one integrated management). Dari Undang-Undang tersebut dapat disimpulkan bahwa penanganan banjir harus ditangani secara terpadu dari bagian hulu, tengah hingga hilir suatu DAS tidak hanya di bagian hilir yang terkena dampak langsung banjir. Penanganan banjir di daerah hilir telah banyak dilakukan oleh berbagai pihak. 
Penelitian ini difokuskan pada penanganan DAS Pesanggrahan karena DAS tersebut mencakup bagian hulu

DAS Angke - Pesanggarahan.

Karakteristik DAS Pesanggrahan (Subandriyo, dkk, 2006) sebagai berikut:

- Panjang sungai utama $=73,68 \mathrm{~km}$

- Luas DAS = 112,06 km2

- Jumlah Ruas Sungai = 105

- Lebar DAS Hulu = 5,615 km

- Kemiringan Sungai Utama Rerata = $0,27 \%$

- Muara : Cengkareng Drain dan selanjutnya ke muara (Teluk Jakarta)

- Sungai Pesanggrahan melewati Kabupaten Bogor (Kecamatan Tanah Sereal, Bojong Gede), Kota Depok (Kec. Sawangan, Limo), Kota Tangerang Selatan, Jakarta Selatan dan kemudian Cengkareng.

Perkembangan permukiman menyebabkan sulitnya infiltrasi sehingga Kali Pesanggrahan meluap dan banjir. Salah satu cara untuk mengurangi dampak banjir di DAS Pesanggrahan adalah dengan normalisasi situ-situ yang berada di hulu DAS. Keberadaan situ di DAS Pesanggrahan sangat mempengaruhi Kali Pesanggrahan. Jumlah situ di wilayah Jabodetabek sendiri ada 200 buah dengan luas total semula $2300 \mathrm{Ha}$ (Zubaidi, 2003). Pengurangan jumlah luasan situ signifikan terjadi pada Jakarta yaitu hampir $100 \%$ dan luas situ tahun 2003 di wilayah Jabodetabek diperkirakan tinggal $1470 \mathrm{Ha}$ (Anshori, 2003). Terdapat 6 buah situ di kawasan DAS Pesanggrahan yaitu sebagai berikut : Situ Gintung, Situ Babakan, Situ Bojongsari, Situ Pasir Putih, Situ Tonjong, dan Situ Kemuning.

\subsection{Situ - Situ pada DAS Pesanggrahan}

Ada 6 di sekitar DAS Pesanggrahan yang telah di bahas sebelumnya. Selanjutnya, mendeliniasi situ-situ tersebut. Dari keenam situ tersebut terdapat satu situ yang sudah tidak berfungsi lagi karena pendangkalan dan telah berubah menjadi perumahan yaitu Situ Pasir Putih (Kwarsa Hexagon,). Pada DAS Pesanggrahan dapat ditentukan 3 situ yang lokasinya berada sekitar hulu yaitu Situ Bojongsari, Situ Tonjong dan Situ Kemuning. Situ Bojongsari berada di Kota Depok, Kec. Sawangan sedangkan Situ Tonjong dan Kemuning berada di Kabupaten Bogor, Kec. Bojonggede.

Situ Bojongsari merupakan situ yang berada di Kecamatan Sawangan dan dikelilingi oleh permukiman yaitu

Perumahan Telaga Golf dan perkampungan Cinangka. Luas Situ Bojongsari adalah 20,27 hektar. Situ Bojongsari dikelola menjadi 3 kawasan yaitu bagian barat (Jembatan pada Situ Bojongsari), bagian tengah dan bagian timur (Gang Enam). Pemanfaatan Situ Bojongsari yaitu tempat wisata dan Perikanan dan pemancingan warga.

Pada tahun 2002 dan 2007 Situ Bojongsari pernah mengalami banjir karena luapan air yang tidak dapat tertampung dan tergenang di jalan sekitar. Pada saat stabil kedalaman Situ Bojongsari mencapai 7 - 9 meter sedangkan 15 tahun lalu kedalaman bisa mencapai 12 meter. Pemanfaatan air situ digunakan untuk irigasi dan sawah. Aliran sungai yang masuk ke dalam Situ Bojongsari adalah 1 Sungai besar yaitu Sungai Ciputat dan 6 sungai kecil. Situ Bojongsari juga memiliki nama lain yaitu Situ 7 Muara karena memiliki 7 muara yaitu 3 di daerah Bojongsari dan 4 di

Sawangan. Pada tahun 2012, penggunaan lahan pada sub DAS Situ Bojongsari adalah pertanian lahan kering, sawah dan permukiman. Berikut ini merupakan peta penggunaan lahan Situ Bojongsari pada Gambar 3. 


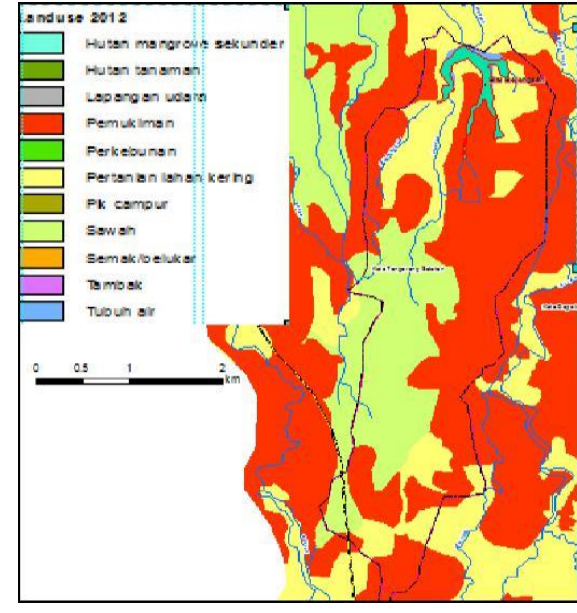

Gambar 3. Peta Penggunaan Lahan Sekitar Situ Bojongsari

Situ Tonjong berada di Kabupaten Bogor Kecamatan Bojong Gede dan memiliki luas sebesar 7,76 hektar. Situ Tonjong memiliki inlet yaitu dari Kali Kemuning, Perumahan Bilabong dan Laguna Residence. Pemanfaatan Situ

Tonjong adalah sebagai tempat pemancingan dan kolam apung. Permasalahan pada Situ Tonjong adalah banyaknya bangunan liar yang didirikan secara illegal di sempadan Situ Tonjong. Outlet dari Situ Tonjong sering terjadi banjir yaitu di Kali Tonjong, Tajurhalang karena mengalami penyempitan. Sedangkan Situ Kemuning berada di Kabupaten Bogor Kecamatan Bojonggede dan memiliki luas 4,4 hektar.

Oleh karena itu, Situ Bojongsari memiliki luas terbesar di antara Situ Tonjong dan Kemuning. Hal tersebut dapat terlihat dari perhitungan hasil digitasi dan deliniasi situ tahun 2015 Situ Bojongsari memiliki luas terbesar yaitu sekitar 20,27 hektar dan berada pada DAS Angke. Luas Situ Bojongsari hampir tiga kali lipat dari luas Situ Tonjong yaitu 7,76 hektar dan lima kali lipat luas Situ Kemuning yang hanya 4,4 hektar. Sedangkan dari segi luas subdas (sub catchment area), Situ Bojongsari juga memiliki luas subdas terbesar di antara kedua situ lainnya yaitu 861,05 hektar. Sedangkan untuk Situ Tonjong memiliki luas subdas terbesar kedua yaitu 270,88 hektar pada DAS Angke dan 164,19 pada DAS Pesanggrahan. SubDAS Situ Kemuning memiliki luas subdas terkecil yaitu hanya 145,31 hektar dan berada pada DAS Pesanggrahan.

Semakin besar luas wilayah subdas dan situ yang ditata sesuai fungsi situ maka akan semakin besar juga pengaruhnya terhadap reduksi risiko bencana banjir di Jakarta. Sehingga dengan adanya penataan kawasan Situ Bojongsari dapat meminimalisir genangan yang berada pada hilir DAS Angke yaitu di Cengkareng dan wilayah hilir lainnya. Selain dari segi luas, berikut ini merupakan sejumlah alasan mengapa bagian hilir dengan dominasi Situ Bojongsari layak terpilih menjadi model penataan kawasan situ.

- Situ Bojongsari telah mendapatkan perhatian khusus dari pemerintah setempat sedangkan kedua situ lainnya belum mendapatkan bantuan ataupunpemeliharaanapapun.

Contohnyaadalahdengan

mendapatkan perhatian seperti adanya pembersihan oleh pemerintah setempat dengan menggunakan dozer pada awal tahun 2016 dan pemantauan yang dilakukan sebulan sekali.

- Terdapat relawan kebersihan oleh pemuda - pemuda masyarakat

setempat terutama Kelurahan Kedaung Bojongsari untuk melakukan pembersihan Situ Bojongsari. Hal tersebut sangat penting dalam kajian penataan Situ Bojongsari karena dalam proses penataan kawasan situ perludukunganpenuholeh

masyarakat setempat secara kooperatif untuk pengambilan data dan sumber informasi kajian.

- Pemanfaatan Situ Bojongsari oleh masyarakat setempat yang sangat beragam dibandingkan dengan Situ

Tonjong dan Kemuning. Situ Bojongsari dimanfaatkan sebagai tempat wisata dan untuk irigasi sawah masyarakat. 


\subsection{Penggunaan Lahan pada SubDAS Situ Bojongsari}

Seiring bertambahnya tahun penggunaan lahan pada SubDAS Situ

Bojongsari mengalami perubahan. Berdasarkan data penggunaan lahan dari Bapelan tahun 2012. Penggunaan lahan permukiman di SubDAS Situ Bojongsari memiliki luas terbesar yaitu 399,34 hektar disusul dengan penggunaan lahan sawah yaitu sebesar 196,09 hektar. Sedangkan klasifikasi tubuh air adalah klasifikasi penggunaan lahan dengan luas terkecil yaitu 14,88 hektar.

Pada tahun 2014 penggunaan lahan pada subdas Situ Bojongsari

mengalami banyak perubahan. Berdasarkan data RBI 2014, koreksi Google Earth 2015 dan verifikasi survey lapang 2016 maka dapat diketahui bahwa penggunaan lahan Subdas Situ Bojongsari terdiri dari 6 klasifikasi.

Pengklasifikasian penggunaan lahan pada tahun 2014 lebih detail dibandingkan pada tahun 2012. Luas Penggunaan Lahan subdas Situ Bojongsari 2014 dapat terlihat bahwa penggunaan lahan dengan luas terbesar adalah tempat tinggal/ permukiman dengan luas sebesar 344,40 hektar. Sedangkan luas penggunaan lahan terkecil yaitu danau/situ yaitu hanya 23,13 hektar.

Penggunaan Lahan Sudas Situ Bojongsari 2012 dan 2014 dapat dilihat pada Tabel 3 sebagai berikut.

Tabel

3. Luas Penggunaan Lahan subDAS Situ Bojongsari 2012 dan 2014

\begin{tabular}{|l|r|r|r|}
\hline \multicolumn{1}{|c|}{ Landuse } & \multicolumn{1}{c|}{$\begin{array}{c}\text { Luas } \\
\mathbf{( H a )} \\
\mathbf{2 0 1 2}\end{array}$} & $\begin{array}{r}\text { Luas } \\
\mathbf{( H a )}\end{array}$ & Selisih \\
\hline $\begin{array}{l}\text { Agrikultur } \\
\text { Ladang }\end{array}$ & 180,04 & 201,78 & 21,74 \\
\hline Danau Situ & 14,88 & 23,13 & 8,25 \\
\hline $\begin{array}{l}\text { Sabana dan } \\
\text { Padang }\end{array}$ & & 89,60 & 89,60 \\
\hline Perkebunan & & 77,00 & 77,00 \\
\hline Sawah & 196,09 & 54,45 & $-141,64$ \\
\hline Permukiman & 399,343 & 344,40 & $-54,94$ \\
\hline Total & 790,36 & 790,36 & \\
\hline
\end{tabular}

Permukiman pada subdas Situ Bojongsari berupa perumahan dan perkampungan. Selain Situ Bojongsari terdapat situ - situ kecil yang berada di sekitar Situ Bojongsari. Namun berdasarkan survei pemanfaatan situ kecil tersebut hanya sebagai tempat menampung air. Penggunaan lahan

yang paling banyak mengalami pengurangan luas adalah sawah yaitu sebesar 141,64 hektar. Area sawah banyak mengalami perubahan menjadi perkebunan dan ladang. Perubahan penggunaan lahan tersebut dapat disebabkan oleh kurangnya persediaan air untuk irigasi sawah sehingga

menguntungkan jika masyarakat menggunakan tanah mereka untuk berkebun.

\subsection{Zona Pemukiman pada SubDAS Situ Bojongsari}

Permukiman yang berada di subDAS Situ Bojongsari terdiri dari

perumahan dan perkampungan. Selanjutnya, dilakukan deliniasi zona permukiman dengan menggunakan data Google Earth tahun 2015. Keterbatasan data citra Google Earth dengan resolusi citra yang terbatas maka deliniasi zona permukiman dibagi menjadi 3 klasifikasi yaitu Zona Permukiman Tipe A, Zona Permukiman Tipe B, dan Zona Permukiman Tipe C.

Zona Permukiman Tipe A didefinisikan terbangun lebih besar dibandingkan dengan luas area tidak terbangun. Area tidak terbangun disini lebih ditekankan pada pekarangan dan halaman warga yang masih berupa tanah atau kebun sehingga masih dapat menyerap air.

Zona permukiman Tipe $B$ didefinisikan sebagai permukiman yang memiliki luas area terbangun yang sebanding dengan luas area tidak

terbangun. Sedangkan Zona Permukiman Tipe C didefinisikan sebagai permukiman yang memiliki luas area terbangun lebih kecil dibandingkan 
luas area tidak terbangun (Dardan, 2009).

Tabel 3. Luas Zona Permukiman Tipe $A, B$ dan $C$ pada subDAS Situ Bojongsari

\begin{tabular}{|l|r|r|}
\hline $\begin{array}{c}\text { Zona } \\
\text { Permukiman }\end{array}$ & $\begin{array}{c}\text { Luas } \\
\text { (Ha) }\end{array}$ & $\%$ \\
\hline Tipe A & 62,48 & 18,14 \\
\hline Tipe B & 245,08 & 71,16 \\
\hline Tipe C & 36,83 & 10,69 \\
\hline Total & 344,40 & 100 \\
\hline
\end{tabular}

Zona permukiman dengan luas terbesar pada subDAS Situ Bojongsari adalah zona permukiman Tipe B yaitu sebesar 245,08 hektar atau $71,16 \%$ dari luas keseluruhan. Zona permukiman tersebut tersebar merata pada subDAS. Sedangkan zona permukiman dengan luas terbesar kedua adalah zona permukiman Tipe A yaitu sebesar 62,48 hektar atau $18,14 \%$ dari luas keseluruhan. Zona permukiman tersebut dominan berada di sepanjang Jalan Bojongsari yang merupakan jalan utama. Zona permukiman dengan luas terkecil adalah zona permukiman Tipe $\mathrm{C}$ yaitu sebesar 36,83 hektar atau 10,69\% dari luas keseluruhan.

\subsection{Rute Survei Penggunaan Lahan SubDAS Situ Bojongsari 2014}

\section{Setelah melakukan deliniasi zona}

permukiman maka selanjutnya melakukan survei melihat kondisi eksisting zona permukiman tipe A, B dan tipe $C$. Sehingga dapat diidentifikasi

perbedaan setiap jenis zona permukiman. Selain itu juga dilakukan survei terhadap penggunaan lahan selain permukiman seperti perkebunan, ladang, alang alang, sawah, kolam dan lain sebagainya. Untuk survei ditentukan 35 titik sampel yang terdiri dari 20 titik sampel zona permukiman dan 15 titik sampel non permukiman. Titik-titik sampel tersebut ditentukan berdasarkan perbedaan jenis zona permukiman dan penggunaan lahan pada subdas Situ Bojongsari.
Titik sampel diletakan secara tersebar sesuai ketersediaan aksesibilitas yang terjangkau pada wilayah kajian. Rute survei yang direncanakan yaitu dibagi menjadi 3 wilayah yaitu

1. Rute A yaitu rute di bagian hilir subdas Situ Bojongsari

2. Rute B yaitu di bagian tengah subdas Situ Bojongsari

3. Rute $C$ yaitu di bagian hulu subdas Situ Bojongsari

Berdasarkan hasil survei di 20 titik sampel zona pemukiman maka dapat

diidentifikasikan kriteria zona permukiman tipe $A, B$, dan $C$ sesuai kondisi eksisting. Zona Permukiman Tipe A memiliki kondisi lingkungan yang didominasi oleh area terbangun dan sebagian besar jalan sudah tertutup oleh aspal dan beton. Zona permukiman Tipe $B$ di bagian hilir merupakan tempat tinggal berupa perkampungan yang masih memiliki kebun di sekitar

perkampungan tersebut. Rata-rata rumah - rumah pada perkampungan tersebut masih memiliki halaman berupa tanah atau pekarangan yang masih dapat menyerap air. Zona permukiman tipe $\mathrm{C}$ merupakan tipe permukiman yang memiliki luas RTH atau area tidak terbangun lebih besar dibandingan area terbangun. Dari ketiga tipe permukiman yang telah dibahas sebelumnya, maka dapat ditarik kesimpulan bahwa permukiman yang paling bagus untuk dijadikan tempat reduksi banjir adalah zona permukiman Tipe C karena masih memiliki area penyerapan air yang sangat luas.

Untuk titik sampel penggunaan lahan non permukiman diketahui memiliki 15 titik sampel. Jumlah titik sampel tersebut lebih kecil dibandingkan dengan jumlah titik sampel permukiman karena kajian pada penataan kawasan situ lebih ditekankan pada penggunaan lahan permukiman di sekitar situ. Sehingga rekomendasi yang akan dibuat dapat cocok untuk setiap jenis zona permukiman pada SubDAS Situ Bojongsari. Pengambilan titik sampel 
pada penggunaan lahan permukiman dilakukan untuk verifikasi data yang telah ada.

\subsection{Metode Penyerapan Air}

Resapan air atau infiltrasi air ke dalam lapisan tanah atau batuan merupakan bagian dari proses siklus air dimana air hujan yang turun ke permukaan bumi sebagian mengalir di permukaan sebagai aliran permukaan (run off) dan sebagian lagi masuk ke dalam tanah mengisi lapisan akuifer untuk kemudian disebut sebagai air tanah (Murtono, 2013). Perubahan penggunaan lahan akibat pembangunan perumahan secara tidak langsung dapat merusak kawasan resapan air padahal kawasan resapan air sangat penting untuk menunjang ketersediaan air tanah.

Lahan yang dulunya merupakan daerah terbuka maupun daerah resapan air (pervious area) berubah menjadi daerah yang tertutup perkerasan yang bersifat kedap air (impervious area). Perubahan penggunaan lahan seperti ini menyebabkan air hujan tidak dapat meresap ke dalam tanah pada musim

penghujan sehingga menimbulkan limpasan di permukaan (surface runoff) yang kemudian menjadi genangan atau banjir (Harisuseno, 2013). Kondisi seperti ini juga akan mempengaruhi

kelestarian airtanah (groundwater) karena air hujan yang meresap ke dalam tanah merupakan imbuhan airtanah secara alami (natural recharge). Berikut ini merupakan metode penyerapan air untuk mereduksi banjir:

\section{Lubang Biopori}

Biopori adalah lubang-lubang dalam tanah yang terbentuk akibat berbagai aktifitas organisme di dalamnya seperti cacing, perakaran tanaman, rayap dan fauna tanah lainnya. Lubanglubang yang terbentuk akan terisi udara dan akan menjadi tempat berlalunya air dalam tanah. Lubang resapan biopori adalah metode resapan air yang ditujukan untuk mengatasi banjir dengan cara meningkatkan daya resap air pada tanah. Teknologi lubang resapan biopori berfungsi untuk mengurangi limpasan air hujan dengan meresapkan lebih banyak volume air ke dalam tanah

sehingga mampu meminimalkan kemungkinan terjadinya banjir. Jumlah lubang resapan biopori ditentukan berdasarkan luas lahan, yaitu setiap 50 meter persegi luas lahan dibuat 10 lubang, sebagai contoh : (1) Untuk luas lahan s/d 50 meter persegi sebanyak 10 lubang; (2) Luas lahan 50 - 100 meter persegi sebanyak 20 lubang; (3) Luas lahan 100 - 150 meter persegi sebanyak 30 lubang. Cara pembuatan lubang biopori adalah sebagai berikut.

- Buat lubang silindris secara vertikal ke dalam tanah dengan diameter 10 $\mathrm{cm}$. Kedalamannya sekitar $100 \mathrm{~cm}$ atau sampai melampaui muka air tanah jika dibuat tanah yang mempunyai permukaan air dangkal. Jarak antar lobang antara 50-100 $\mathrm{cm}$.

- Mulut lubang dapat diperkuat dengan semen selebar 2-3 cm setebal $2 \mathrm{~cm}$.

- Isi lubang dengan sampah organik yang berasal dari sampah dapur, sisa tanaman, atau dedaunan.

- Sampah organik perlu ditambahkan jika isi lubang sudah berkurang atau menyusut akibat proses pelapukan.

- Kompos yang terbentuk dalam lubang dapat diambil pada setiap akhir musim kemarau bersamaan dengan pemeliharaan lubang.

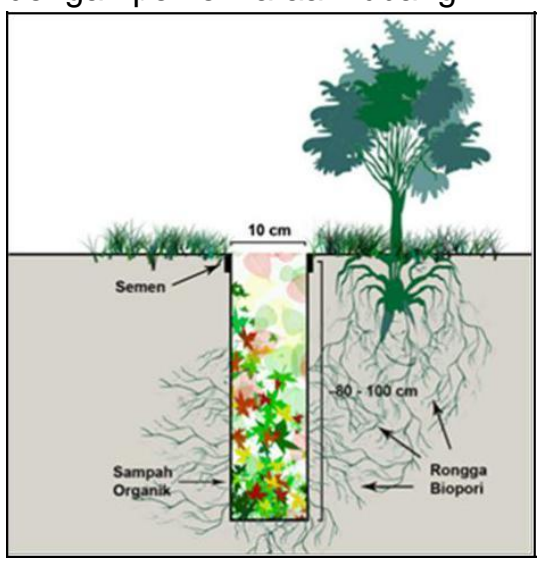

Gambar 3. Lubang Biopori

Sumber: Biopori.com 


\section{Sumur Resapan}

Salah satu solusi lainnya untuk mengatasi banjir pada kawasan perumahan dapat dilakukan dengan cara pencegahan melalui perencanaan dari awal oleh pihak pengembang perumahan dengan mengalokasikan lahan untuk pembuatan sumur resapan . Sumur resapan berfungsi sebagai tempat menampung air hujan sementara yang jatuh di atas atap rumah, kemudian air hujan tersebut akan diserap oleh tanah secara perlahan sehingga limpasan air hujan tidak langsung mengalir ke saluran drainase (Gemilang, 2013).

Persyaratan umum dibuatnya sumur resapan adalah sebagai berikut:

- Sumur resapan air hujan dibuat pada lahan yang lolos air dan tahan longsor.

- Sumur resapan air hujan harus bebas dari pencemaran air limbah.

- Air yang masuk ke sumur resapan adalah air hujan.

- Daerah sanitasi lingkungan yang buruk, sumur resapan air hujan hanya menampung dari atap dan disalurkan melalui talang.

- Mempertimbangkan aspek hidrogeologi, geologi dan hidrologi.

Sedangkan persyaratan keadaan topografi adalah sebagai berikut

- Lahan dengan kemiringan $>15^{\circ}$ seharusnya tidak diizinkan untuk dibuat sumur resapan untuk menghindari kelongsoran di areal pemukiman penduduk.

- Lahan dengan kemiringan $11^{0}-15^{0}$ merupakan lahan dengan sudut kemiringan kritis.

- Lahan dengan kemiringan $<11^{0}$ aman dari kemungkinan bahaya longsor sepanjang sipat batuannya tidak rawan longsor.

Persyaratan permeabilitas dan muka air tanah:

- Permeabilitas tanah yang cocok untuk dijadikan tempat sumur resapan adalah minimal $2 \mathrm{~cm} / \mathrm{jam}$.

- Tanah yang mempunyai permeabilitas dibawah dari itu tidak direkomendasikan untuk dibangun sumur resapan karena tanah tersebut sudah jenuh air dan dapat menyebabkan genangan di dalam sumur.

- Muka air tanah di lokasi dibangunnya sumur resapan harus ( lebih besar) dari $>3 \mathrm{~m}$.

Berbeda dengan pembuatan lubang biopori, membuat sumur resapan air memang membutuhkan biaya yang lebih besar dan lahan yang relative lebih luas. Selain itu tidak semua lahan dapat dibuat sumur resapan, harus memperhatikan syarat-syarat umum sebagai tersebut di atas.

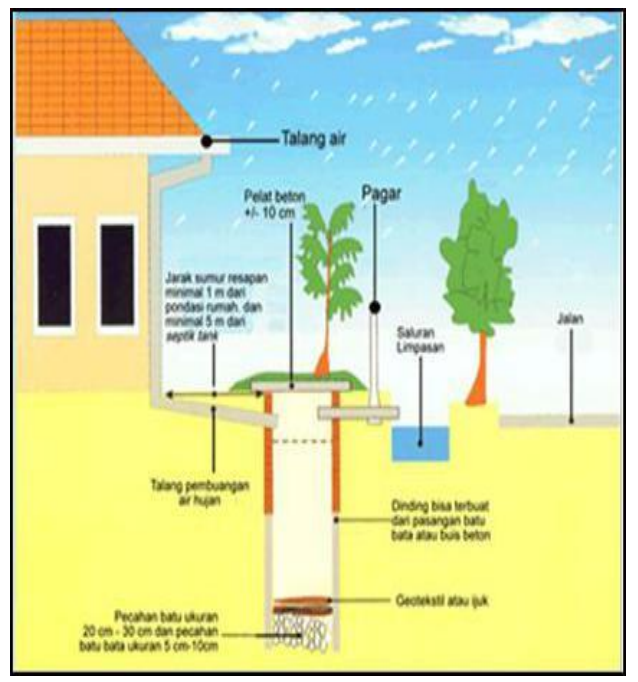

Gambar 4. Sumur Resapan

Sumber: http://www.menlh.go.id

Berdasarkan penjelasan mengenai beberapa tipe zona pemukiman dan metode penyerapan air pada pembahasan sebelumnya maka diperoleh bahwa lubang biopori cocok dengan kriteria zona permukiman tipe $A$ yang luas ruang terbuka hijaunya terbatas. Zona permukiman tipe B masih memiliki lahan yang cukup luas untuk pembuatan sumur resapan dan lubang biopori. Banyak warga yang memiliki kebun di samping rumah mereka sehingga pembuatan sumur resapan dapat dilakukan pada lahan-lahan tersebut. Namun masih juga ditemukan 
rumah yang halamannya kecil sehingga lebih cocok menggunakan metode lubang biopori. Metode penyerapan air yang cocok pada zona permukiman tipe $C$ yang memiliki kriteria halaman yang luas dan memiliki ruang terbuka hijau (RTH) yang luas adalah sumur resapan. Gambar 9. di bawah ini merupakan wilayah rekomendasi metode penyerapan air di setiap zona permukiman.

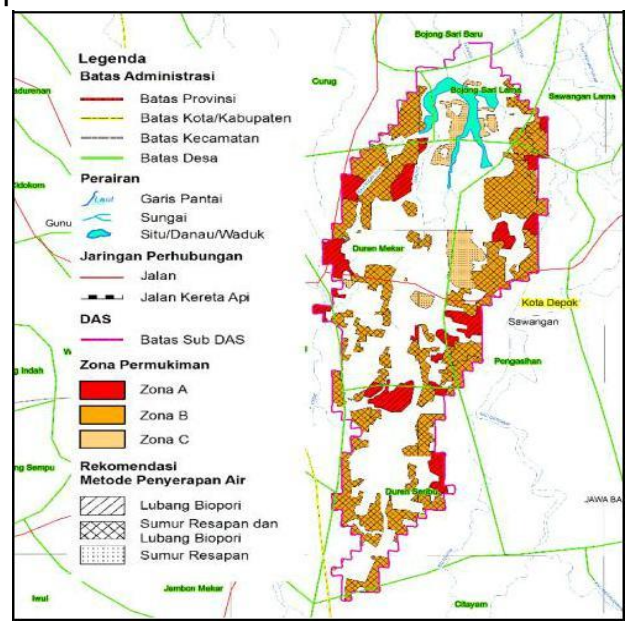

Gambar 6. Rekomendasi Metode

Penyerapan Air di Setiap Zona

Permukiman pada subDAS Situ

Bojongsari

Sumber: Analisis Data, 2016

\section{KESIMPULAN}

Kesimpulan yang diperoleh dari pembahasan bab sebelumnya adalah sebagai berikut:

1. Metode penyerapan air yang cocok dengan zona permukiman tipe $A$ adalah dengan lubang biopori.

2. Metode penyerapan air yang cocok dengan zona permukiman tipe $B$ adalah sumur resapan dan lubang biopori.

3. Metode penyerapan air yang cocok pada zona permukiman tipe $\mathrm{C}$ adalah sumur resapan.

\section{DAFTAR PUSTAKA}

Anshori, I. 2003. Pengelolaan Situ di Wilayah Ciliwung Cisadane. Direktorat PSDA, Direktorat Jenderal Sumberdaya Air, Departemen Kimpraswil.

Darda, Aji M. 2009. Karakteristik Permukiman di Wilayah Pinggiran Kota Jakarta Tahun 1991 - 2007. Depok: Universitas Indonesia.

Gemilang, Galih. 2013. Kajian Sumur Resapan Dalam Mereduksi Debit Banjir Pada Kawasan Perumahan (Studi Kasus: Perumahan Anugerah Lestari Kuala Gumit, Langkat). Medan: Teknik Sipil Universitas Sumatera Utara.

Harisuseno, Donny. 2013. Studi Sebaran Kawasan Resapan (Permeable

Area) pada Berbagai Tipe Penggunaan Lahan. Malang: Universitas Brawijaya.

Kwarsa Hexagon, PT. Studi Pendahuluan Penanganan Konservasi dan Pengembangan Sumberdaya Air di Wilayah Sungai Ciliwung-Cisadane, Direktorat Sungai dan Danau, Direktrat Jenderal Penataan Ruang dan

Pengembangan Wilayah, Departemen Kimpraswil.

Murtono, Teggu. 2013. Zonasi Imbuhan Air Tanah Pada Daerah Aliran Sungai Lahumbuti Provinsi Sulawesi Tenggara. Makassar: Teknik Geologi Universitas Hasanudin.

Rosyidie, Arief. 2013. Banjir: Fakta dan Dampaknya, Serta Pengaruh dari Perubahan Guna Lahan. Jurnal Perencanaan Wilayah dan Kota, Vol. 24 No. 3, Desember 2013, hlm. 241 - 249 .

Syarif, Achmad. 2008. Wilayah Banjir di Hilir Kali Angke Tahun 2002. Depok: Universitas Indoensia.

Subandriyo, Pitoyo, dkk. 2006. Pengendalian Banjir Kali Pesanggrahan Berwawasan Terpadu dan Berkelanjutan. 
Zubaidi, A. 2003. Revitalisasi Situ-Situ di Jabodetabek. Direktorat Jenderal Bina Pembangunan Daerah, Departemen Dalam Negeri.

---, http://www.menlh.go.id.

---, Google Earth, Diakses pada 2015.

---, Google Street Map, Diakses pada 2016. 